\title{
PERAN KOMITE MADRASAH DAN KEPEMIMPINAN KEPALA MADRASAH DALAM MENINGKATKAN MUTU PENDIDIKAN ISLAM
}

\author{
Ahmad Manshur \\ IAI Sunan Giri Bojonegoro \\ Email: ahmanshur@gmail.com
}

\begin{abstract}
Abstrak : "The relationship of madrasah with society is essentially a very instrumental in fostering and developing personal growth of learners in madrasah, in this case madrasah as a social system is an integral part of the larger system of society. On the other hand, madrasah should support the achievement of community goals, especially education needs. Therefore, madrasah should also know clearly what the needs and circumstances of society, especially against madrasah. The cause of the low quality of education in Indonesia certainly can not be separated from the role and leadership of a teacher as top leadernya. The madrasah committee has an important role as a giver of balance, support, control, and as a mediator between government and society in educational units. Head of madrasah as top leader in Islamic education institution hence head of madrasah of course have role of strategy in influencing all stakeholder of madrasah to reach goal of education of Islam. Together the madrasah committee and the head of madrasah in improving the quality of Islamic education in madrasah."
\end{abstract}

Key Word: Madrasah Committee, Leadership of Madrasah Head, and Quality of Islamic Education

\section{A. Pendahuluan}

Salah satu permasalahan pendidikan yang dihadapi oleh bangsa Indonesia adalah rendahnya kualitas pendidikan pada setiap jenjang dan satuan pendidikan, khususnya pendidikan dasar dan menengah. Berbagai usaha telah dilakukan untuk meningkatkan mutu pendidikan nasional, misalnya dengan pengembangan kurikulum, peningkatan mutu guru, perbaikan sarana pendidikan, pengadaan buku dan alat peraga, serta peningkatan mutu manajemen madrasah. Namun demikian, berbagai indikator mutu pendidikan belum menunjukkan peningkatan yang berarti. Sebagian madrasah memang telah menunjukkan peningkatan mutu pendidikan yang 
cukup menggembirakan, namun pada umumnya, sebagian besar lainnya masih memprihatinkan. ${ }^{1}$

Madrasah merupakan salah satu unit penting yang keberadaannya tidak bisa dilepaskan dari masyarakat. Oleh karena itu madrasah harus mengorientasikan programnya agar peserta didik mampu berperan dalam kehidupan sehari-hari di lingkungannya. Selain tuntutan global dan nasional, madrasah juga dihadapkan pada berbagai macam tuntutan lokal, sehingga kepedulian masyarakat sangat signifikan. Sehubungan dengan itu yang harus dilakukan adalah bagaimana madrasah mampu menjalin hubungan yang baik dan bersifat timbal balik dengan masyarakat dan lingkungan sekitar.

Disamping itu, sebagai salah satu sub-sistem pendidikan nasional yang menyelenggarakan pendidikan, berkewajiban memajukan pendidikan nasional serta ikut bertanggungjawab dalam meningkatkan mutu pendidikan. Disadari bahwa baru sebagian sekolah yang memiliki prestasi dalam mutu pendidikan yang diunggulkan. Oleh karena itu, pembentukan komite sekolah merupakan langkah strategis dalam upaya peningkatan mutu pendidikan. Keberadaan komite sekolah merupakan prasayarat mutlak bagi implementasi manajemen berbasis sekolah (MBS) yang efektif dan efisien. ${ }^{2}$

Hubungan madrasah dengan masyarakat pada hakikatnya merupakan sarana yang sangat berperan dalam membina dan mengembangkan pertumbuhan pribadi peserta didik di madrasah, dalam hal ini madrasah sebagai sistem sosial merupakan bagian integral dari sistem yang lebih besar yaitu masyarakat. Madrasah dan masyarakat memiliki hubungan yang erat dalam mencapai tujuan madrasah atau pendidikan secara efektif, efisien. Sebaliknya madrasah harus menunjang pencapaian tujuan masyarakat khususnya kebutuhan pendidikan. Oleh karena itu madrasah juga harus mengetahui dengan jelas apa kebutuhan serta keadaan masyarakat terutama terhadap madrasah.

Melalui pelaksanaan MBS, keberadaan peran dan fungsi komite madrasah diharapkan mampu meningkatkan kinerja program pengelolaan pendidikan di madrasah, sehingga mutu pendidikan meningkat secara optimal. Keterlibatan komite madrasah dalam memberi pertimbangan (advisory), dukungan (supporting), dan

\footnotetext{
${ }^{1}$ Sadili Samsudin, Manajemen Sumber Daya Manusia. Bandung, CV.Pustaka Setia, 2006, hal. 98

${ }^{2}$ Khoiruddin dan Mahfud Junaedi. Kurikulum Tingkat Satuan Pendidikan. Pilar Media. Jakarta, 2007, hal. 248
} 
pengontrol (Controlling) kebijaksanaan madrasah serta mediator antara pemerintah. Madrasah dengan masayarakat di satuan pendidikan tidak dipandang sebagai loyalitas masyarakat atas pemerintahnya, melainkan juga bahwa kebijakan tersebut hendaknya dianggap sebagai miliknya sendiri. ${ }^{3}$

Namun demikian tidak selamanya imeg negatif serta kenyataan-kenyataan seperti yang diungkapkan di atas melekat pada semua komite madrasah, karena ada pula sebagian komite madrasah yang mampu menyusun dan melaksanakan program dengan baik dalam mendukung pelaksanaan pendidikan di suatu madrasah, sehingga mendapat kepercayaan dari masyarakat.

Dalam hal menilai tentang peran komite dan gaya kepemimpinan kepala madrarasah serta keberhasilan-keberhasilan yang dicapai dan kegagalankegagalannya dalam mendukung pelaksanaan pendidikan, tentunya hal ini ditunjang oleh kemampuan komite dan kepala madrasah dalam menyusun dan melaksanaan program serta upaya komite madrasah dan kepala madrasah dalam menanggulangi kendala-kendala yang dihadapi komite madrasah.

Hal ini menjadi suatu yang menarik untuk dibahas lebih lanjut, untuk menghapus imeg negatif masyarakat tentang keadaan komite madrasah dalam kenyataan yang ada di sebagian komite madrasah serta menjadi bahan introspeksi bersama untuk lebih meningkatkan fungsi dan peran kita masing-masing, mengingat bahwa pendidikan adalah menjadi tanggung-jawab semua elemen bangsa.

Kerjasama lembaga pendidikan dengan komite madrasah merupakan bukti kepedulian dan tanggung-jawab mereka tehadap dunia pendidikan. Para orang tua telah menitipkan anak mereka pada lembaga agar diajar dan dididik oleh guru, sehingga anak-anak mereka kelak menjadi anak yang sholeh/sholehah dan mengenal siapa penciptanya. Setelah dititipkan, anak-anak tersebut menjadi tanggung-jawab guru sepenuhnya di madrasah. Sedangkan oang tua sebagai wali murid berkewajiban memenuhi segala keperluan anaknya yang berhubungan dengan pendididkan mereka, seperti : memberikan seragam madrasah, membelikan alat tulis, membayar uang madrasah dan lain-lain. Sebagai wujud kerjasamanya tidak sedikit orang tua/wali murid yang turut ambil bagian dalam pembangunan suatu madrasah di mana anakanak mereka menuntut ilmu. Dengan niat jihad fisabilillah dan demi pendiddikan anak-anak mereka dan demi masa depan bangsa dan agama, baik dengan harta, serta

\footnotetext{
${ }^{3}$ Ibid., hal. 101
} 
dengan akal pikiran dan ide-ide mereka. Dengan adanya kerja sama seperti ini maka hubungan madrasah dengan komite madrasah tetap terjaga.

Sumber daya manusia yang handal tidak lepas dari pengaruh pola kepemimpinan yang diterapkan dalam sebuah organisasi. Kepemimpinan merupakan suatu proses yang mengandung unsur mempengaruhi, adanya kerjasama dan mengarah pada suatu hal dan tujuan bersama dalam sebuah organisasi. Kepemimpinan mempunyai peranan sentral dalam dinamika kehidupan organisasi. Kepemimpinan berperan sebagai penggerak segala sumber daya manusia dan sumber daya lain yang ada dalam organisasi. ${ }^{4}$

Keberhasilan organisasi mencapai tujuan yang telah ditetapkan akan sangat tergantung berperannya kepemimpinan. Berdasarkan data di situs internet sebagai berikut: "Kepala harus mampu menggerakkan staf guru dan staf tata usaha untuk melaksanakan fungsi supervisi. Kepala bertanggung jawab atas penyelenggaraan kegiatan pendidikan, administrasi madrasah, pembinaan tenaga pendidikan dan pendayagunaan serta pemeliharaan sarana prasarana". 5

Kemampuan seorang kepala dalam memimpin akan sangat berpengaruh dalam meningkatkan mutu pendidikan. Apabila guruselaku pimpinan dalam menjalankan tugasnya kurang baik, akan berakibat kurangnya motivasi kerja para guru, sehingga akan mempengaruhi efektivitas kerja guru, maka peran pemimpin sangat penting sebab pemimpin memegang peran dalam menentukan tercapai atau tidaknya tujuan madrasah/organisasi tersebut

\section{B. Komite Madrasah}

\section{Pengertian Komite Madrasah}

Komite madrasah adalah sebuah kalimat yang terdiri dari dua kata yakni "Komite" dan "Madrasah" yang mempunyai makna yang berbeda. Oleh karena itu sebelum pengertian komite madrasah di bicarakan maka terlebih dahulu harus diketahui masing-masing katanya.

Dalam kamus besar bahasa Indonesia dicantumkan bahwa "Komite adalah panitia yang terdiri dari beberapa unsur atau anggota yang dibebani tugas." Sedangkan kata "Madrasah adalah bangunan atau lembaga tempat untuk belajar

4 Arifin, Abdullrachman, Teori Pengembangan clan Filosofi Kepemimpinan Kerja.: Jakarta, Ikhtiar Baru, 2004, hal. 23

5 Slamet PH., "Karakteristik Kepala Madrasah Tangguh."”Jurnal Pendidikan dan Kebudayaan. (No. 025 tahun VI), 2000, hal. 46

${ }^{6}$ Depdikbud, Kamus Besar Bahasa Indonesia, Pustaka Setia, Jakarta, 1992, hal. 343. 
dan mengajar serta tempat menerima dan memberi pelajaran."7 Setelah menelusuri uraian di atas maka dapat difahami mengenai makna kata "Komite" dan "Madrasah." Komite pada dasarnya adalah sekumpulan orang yang mempunyai beban dalam menjalankan suatu aktivitas. Sedangkan Madrasah adalah tempat atau lembaga yang dipakai dalam rangka menuntut ilmu pengetahuan.

Dengan demikian "Komite Madrasah adalah badan mandiri yang mewadahi peran serta masyarakat dalam rangka meningkatkan mutu, pemerataan dan efesiensi pengelolaan pendidikan di satuan pendidikan baik pendidikan pra madrasah, jalur pendidikan madrasah maupun jalur pendidikan luar madrasah."

Didalam Undang-undang RI tentang Sistem Pendidikan Nasional dijelaskan bahwa komite madrasah adalah lembagaa mandiri yang beranggotakan orang tua/wali peserta didik, komunitas madrasah, serta tokoh masyarakat yang peduli pendidikan. ${ }^{9}$

Dari definisi yang telah dikemukakan di atas. Bahwa komite madrasah pada dasarnya mempunyai makna yang sama dengan Badan Pembantu Penyelenggara Pendidikan (BP3) yang sama-sama ikut serta dalam membantu kelancaran pendidikan di lingkungan madrasah.

\section{Peran Komite Madrasah}

Peran yang dapat dijalankan komite madrasah adalah sebagai berikut:

1. Pemberi perimbangan (advisory agency) dalam penentuan dan pelaksanaan kebijakan pendidikan di satuan pendidikan.

2. Pendukung (supporting agency), baik yang berwujud finansial, pemikiran, maupun tenaga dalam penyelenggaraan pendidikan di satuan pendidikan.

3. Pengontrol (controlling agency) dalam rangka transparansi dan akuntabilitas penyelenggaraan pendidikan di satuan pendidikan.

4. Mediator antara pemerintah (executive) dengan masyarakat di satuan pendidikan. $^{10}$

\footnotetext{
${ }^{7}$ Ibid, hal.511.

${ }^{8}$ Mahfud Junaed, KTSP, Pilar Media, Jakarta, 2007, hal. 249

${ }^{9}$ UURI Nomor 20 Tahun 2003, Sistem Pendidikan Nasional, Jilid 4. Citra Umbara. Jakarta:5

${ }^{10}$ Khoiruddin, Kurikulum Tingkat Satuan Pendidikan. Jilid I. Pilar Media. Jakarta, 2007, hal.251.
} 


\section{Kepemimpinan Kepala Madrasah}

\section{Pengertian Kepemimpinan}

Konsep tentang kepemimpinan dalam dunia pendidikan tidak bisa terlepas dari konsep kepemimpinan secara umum. Konsep kepemimpinan secara umum sering dipersamakan dengan manajemen, padahal dua hal tersebut memiliki perbedaan yang cukup berarti.

Dalam buku kepemimpinan karangan Miftah Toha mengartikan bahwa : "Kepemimpinan adalah aktivitas untuk mempengaruhi orang-orang supaya diarahkan untuk mencapai tujuan organisasi.",11

Pengertian di atas didukung oleh pendapat Stephen P. Robbins dalam buku Manajement, Seven edition yang dialih bahasa oleh T. Hermaya memberikan arti kepemimpinan sebagai berikut: "Kepemimpinan adalah proses mempengaruhi kelompok menuju tercapainya sasaran". ${ }^{12}$ Sedangkan menurut AlanTucker dalam Syafarudin mengemukakan bahwa: "kepemimpinan sebagai kemampuan mempengaruhi atau mendorong seseorang atau sekelompok orang agar bekerja secara sukarela untuk mencapai tujuan tertentu atau sasaran dalam situasi tertentu". ${ }^{13}$ Hal ini memberikan suatu perspektif bahwa seorang manajer dapat berperilaku sebagai seorang pemimpin, asalkan dia mampu mempengaruhi perilaku orang lain untuk mencapai tujuan tertentu. Tetapi seorang pemimpin belum tentu harus menyandang jabatan manajer.

Menurut Andrew J. Dubrin dalam Buku The Complete Ideal's Guides to Leadership $2^{\text {nd }}$ Edition yang dialih bahasa oleh Tri Wibowo BS arti kepemimpinan yang sesungguhnya dapat dijelaskan dengan banyak cara. Berikut ini adalah beberapa definisinya :

a. Kepemimpinan adalah upaya mempengaruhi banyak orang melalui komunikasi untuk mencapai tujuan.

b. Kepemimpinan adalah cara mempengaruhi orang dengan petunjuk atau perintah

c. Kepemimpinan adalah tindakan yang menyebabkan orang lain bertindak atau merespon dan menimbulkan perubahan positif.

\footnotetext{
${ }^{11}$ Miftah Toha, Kepemimpinan dalam Manajemen. Jakarta, PT Raja Grapindo, 2003, hal. 5

${ }^{12} \mathrm{Ibid}$, hal. 12

${ }^{13}$ Tjiptono, F., dan Diana, A, Total Quality Management, Yogyakarta: Penerbit Andi, 2003, hal.49
} 
d. Kepemimpinan adalah kekuatan dinamis penting yang memotivasi dan mengkoordinasikan organisasi dalam rangka mencapai tujuan.

e. Kepemimpinan adalah kemampuan untuk menciptakan rasa percaya diri dan dukungan diantara bawahan agar tujuan organisasional tercapai. ${ }^{14}$

Kepemimpinan sebenarnya dapat berlangsung dimana saja, karena kepemimpinan merupakan proses mempengaruhi orang lain untuk melakukan sesuatu dalam rangka mencapai maksud tertentu. Berdasarkan definisi kepemimpinan yang berbeda terkandung kesamaan arti yang bersifat umum.

Seorang pemimpin merupakan orang yang memberikan inspirasi, membujuk, mempengaruhi dan memotivasi orang lain. Untuk membedakan pemimpin dari non-pemimpin dapat dilakukan dengan menggunakan pendekatan teori perilaku.

Menurut Stephen P Robbins dalam buku Management, Seven Edition yang dialih bahasa oleh T. Hermaya menyatakan bahwa: "Teori prilaku adalah teoriteori kepemimpinan yang mengenali perilaku yang membedakan pemimpin yang efektif dari yang tidak efektif'. Teori perilaku ini tidak hanya memberikan jawaban yang lebih pasti tentang sifat kepemimpinan, tetapi juga mempunyai implikasi nyata yang cukup berbeda dari pendekatan ciri.

\section{Kepemimpinan kepala madrasah}

Kepemimpinan merupakan salah satu faktor yang sangat penting dalam suatu organisai karena sebagian besar keberhasilan dan kegagalan suatu organisasi ditentukan oleh kepemimpinan dalam organisasi tersebut. Yang dimaksud dengan kepemimpinan seperti yang dikemukakan oleh James M. Black pada Manajemem: a Guide to Executive Command adalah kemampuan meyakinkan dan menggerakkan orang lain agar mau bekerja sama di bawah kepemimpinannya sebagai suatu tim untuk mencapai suatu tujuantertentu. ${ }^{15}$

Sementara R. Soekarto Indrafachrudi mengartikan kepemimpinan sebagai suatu kegiatan dalam membimbing suatu kelompok sedemikian rupa sehingga tercapailah tujuan itu. ${ }^{16}$ Kemudian menurut Maman Ukas kepemimpinan adalah kemampuan yang dimiliki oleh seseorang untuk dapat mempengaruhi orang lain,

\footnotetext{
${ }^{14}$ Tilaar, H. A. R. Manajemen Pendidikan Nasional, Bandung: Remaja Rosdakarya, 1997, hal. 4

${ }^{15}$ Sadili Samsudin, Manajemen Sumber Daya Manusia. Bandung, CV. Pustaka Setia, 2006, hal.287

${ }^{16}$ Soekarto Indarafachrudi, Bagaimana Memimpin Madrasah Yang Efektif, Bogor, Ghalia Indonesia, 2006, hal. 2
} 
agar ia mau berbuat sesuatu yang dapat membantu pencapaian suatu maksud dan tujuan. $^{17}$

Berdasarkan beberapa definisi di atas dapat disimpulkan bahwa kepemimpinan adalah kemampuan yang dimiliki seseorang dalam mempengaruhi orang lain untuk mau bekerja sama agar mau melakukan tindakan dan perbuatan dalam mencapai tujuan bersama.

Pemimpin pada hakikatnya adalah seseorang yang mempunyai kemampuan untuk mempengaruhi perilaku orang lain di dalam kerjanya dengan menggunakan kekuasaan. Kekuasaaan adalah kemampuan untuk mengarahkan dan mempengaruhi bawahan sehubungan dengan tugas-tugas yang harus dilaksanakannya. Semakin banyak jumlah sumber kekuasaan yang tersedia bagi pemimpin, maka makin besar potensi kepemimpinan yang efektif. ${ }^{18}$ Menurut kodrat serta irodatnya bahwa manusia dilahirkan untuk menjadi pemimpin.

Namun demikian, walaupun dari definisi kepemimpinan tersebut bertitik tolak dari pemberian pengaruh kepada orang lain untuk melaksanakan apa yang dikehendaki pemimpin untuk menuju suatu tujuan secara efektif dan efisien, namun tenyata proses mempengaruhinya dilakukan secara berbeda-beda. Proses pelaksanaan kegiatan mempengaruhi yang berbeda inilah yang kemudian menghasilkan tingkatan-tingkatan dalam kepemimpinan.

Kepala madrasah adalah seorang pemimpin madrasah atau pemimpin suatu lembaga tempat menerima dan memberi pelajaran. Kepala madrasah adalah seorang tenaga fungsional guru yang diberi tugas untuk memimpin suatu madrasah di mana diselenggarakan proses belajar mengajar, atau tempat di mana terjadi interaksi antara guru yang memberi pelajaran dan murid yang menerima pelajaran. ${ }^{19}$ Kepala madrasah adalah seorang guru (jabatan fungsional) yang diangkat untuk menduduki jabatan struktural (kepala madrasah) di madrasah. ${ }^{20}$

Kepala madrasah adalah sorang guru yang mempunyai kemampuan untuk memimpin segala sumber daya yang ada pada suatu madrasah sehingga dapat didayagunakan secara maksimal untuk mencapai tujuan bersama.

\footnotetext{
${ }^{17}$ Maman Ukas, Manajemen. Bandung. Agini, 2004, hal. 268

${ }^{18}$ Nanang Fatah, Manajemen Pendidikan, Bandung, Remaja Rosdakarya, 2009, hal. 88

${ }^{19}$ Wahjosumidjo, Kepemimpinan dan Motivas. Bogor. Ghalia Indonesia, 2002, hal. 83

${ }^{20}$ Rahman. et.al, Peran Strategi Kepala Madrasah dalam Meningkatkan Mutu Pendidikan, Jatinegara, Alqaprint, 2006, hal. 106
} 
Kepala madrasah merupakan salah satu komponen pendidikan yang paling berperan dalam meningkatkan kualitas pendidikan. Sebagaimana dikemukakan dalam Pasal 12 ayat 1 PP 28 tahun 1990 bahwa kepala madrasah bertanggungjawab atas penyelenggaraan kegiatan pendidikan, administrasi madrasah, pembinaan tenaga kependidikan lainnya, dan pendayagunaan serta pemeliharaan sarana dan prasarana. ${ }^{21}$

Ketercapaian tujuan pendidikan sangat bergantung pada kecakapan dan kebijaksanaan kepemimpinan kepala madrasah yang merupakan salah satu pemimpin pendidikan. Karena kepala madrasah merupakan seorang pejabat yang profesional dalam organisasi madrasah yang bertugas mengatur semua sumber organisasi dan bekerjasama dengan guru-guru dalam mendidik siswa untuk mencapai tujuan pendidikan.

Dengan keprofesionalan kepala madrasah ini pengembangan profesionalisme tenaga kependidikan mudah dilakukan karena sesuai dengan fungsinya, kepala madrasah memahami kebutuhan madrasah yang ia pimpin sehingga kompetensi guru tidak hanya mandeg pada kompetensi yang ia miliki sebelumnya, melainkan bertambah dan berkembang dengan baik sehingga profesionalisme guru akan terwujud.

Madrasah sebagai pendidikan formal bertujuan membentuk manusia yang berkepribadian, dalam mengembangkan intelektual peserta didik dalam rangka mencerdaskan kehidupan bangsa. Kepala madrasah sebagai pemimpin pada sebuah lembaga pendidikan formal, punya peran sangat penting dan menentukan dalam membantu para guru dan muridnya. Didalam kepemimpinnya kepala madrasah harus dapat memahami, mengatasi dan memperbaiki kekurangankekurangan yang terjadi di lingkunagn madrasah secara menyeluruh.Untuk meningkatkan kualitas pendidikan di madrasah yang dipimpinnya, seorang kepala madrasah harus mampu meningkatkan kinerja para pendidik (baca: guru) termasuk tenaga kependidikan yang berada di bawah kewenangannya.

Banyak faktor yang dapat mempengaruhi kinerja seorang guru. Maka sebagai pimpinan tertinggi di madrasah, seorang kepala madrasah harus mampu memberikan energi positif yang mampu menggerakkan para guru untuk melaksanakan tugasnya secara sungguh-sungguh dan penuh tanggung jawab

\footnotetext{
${ }^{21}$ Depdiknas, Manajemen Peningkatan Mutu Berbasis Madrasah, Jakarta, Depdiknas, 2001, hal. 23
} 
sehingga kinerja mereka menjadi lebih baik dan lebih baik lagi. Sebagai pemimpin yang mempunyai pengaruh, seorang kepala madrasah harus terus berusaha agar ide, nasehat, saran dan (jika perlu)instruksi dan perintah dan kebijakannya di ikuti oleh para guru binaannya. Dengan demikian ia dapat mengadakan perubahanperubahan dalam cara berfikir, dalam bersikap dan dalam bertindak atau berperilaku. Maka menjadi tuntutan bagi seorang kepala madrasah harus selalu merefresh pengetahuan dan wawasan keilmuannya agar nantinya dapat mendukung tugasnya sebagai seorang pimpinan.

Banyak faktor penghambat tercapainya kualitas kepemimpinan seorang kepala madrasah seperti proses pengangkatannya tidak transparan, rendahnya mental kepala madrasah yang ditandai dengan kurangnya motivasi dan semangat serta kurangnya disiplin dalam melakukan tugas dan seringnya datang terlambat, wawasan kepala madrasah yang masih sempit serta banyak faktor lain yang menghambat kinerja seorang kepala madrasah untuk meningkatkan kualitas pendidikan pada lembaga yang dipimpinnya. Ini mengimplikasikan rendahnya produktivitas kerja kepala madrasah yang berimplikasi juga pada mutu (input, proses dan output).

\section{Mutu Pendidikan}

\section{Pengertian Mutu Pendiidkan}

Dalam kamus bahasa Indonesia dijelaskan bahwa mutu adalah ukuran baik buruk suatu benda, keadaan, taraf, atau derajad (kepandaian, kecerdasan, dan sebagainya). ${ }^{22}$ Menurut Sudarwan Danim mendefinisikan kualitas sebagai derajad keunggulan suatu produk atau hasil kerja, baik berupa barang atau jasa. ${ }^{23}$ Sedangkan D.L. Goetsch dan Davis, seperti dikutip oleh Fandy Tjiptono dan Anastasia Diana, mendefinisikan kualitas sebagai suatu kondisi dinamis yang berhubungan dengan produk, jasa, manusia, proses, dan lingkungan yang memenuhi atau melebihi harapan. ${ }^{24}$

Sementara itu, jika dilihat dari segi korelasi mutu dengan pendidikan, sebagaimana yang dikemukakan oleh Dzaujak Ahmad, bahwa mutu pendidikan

\footnotetext{
${ }^{22}$ Depdikbud, Kamus Besar Bahasa Indonesia, Jakarta, Pustaka Setia, 1998, hal. 654

${ }^{23}$ Syah, Muhibbin, Psikologi Pendidikan dengan Pendekatan Baru, Bandung, PT Remaja Rosda Karya, 2004, hal. 117

${ }^{24}$ Umiarso \& Imam Gojali, Manajemen Mutu Madrasah di Era Otonomi Pendidikan, Jogjakarta, Ircisod, 2010, hal. 124
} 
adalah kemampuan madrasah dalam pengelolaan secara operasional dan efisien terhadap komponen-komponen yang berkaitan dengan madrasah, sehingga menghasilkan nilai tambah terhadap komponen tersebut menurut norma/standar yang berlaku.

Menurut Omar Hamalik, pengertian mutu dapat dilihat dari dua sisi, yaitu segi normatif dan segi deskriptif. Dalam arti normatif, mutu ditentukan berdasarkan pertimbangan (kriteria) intrinsik dan ekstrinsik. Berdasarkan kriteria instrinsik, mutu pendidikan merupakan produk pendidikan yakni manusia yang terdidik, sesuai dengan standar ideal,. Berdasarkan kriteria ekstrinsik, pendidikan merupakan instrumen untuk mendidik tenaga kerja yang terlatih.

Definisi mutu pendidikan berpusat pada upaya pemenuhan kebutuhan dan keinginan pelanggan serta ketepatan penyampainya untuk mengimbangi harapan pelanggan. Kualitas jasa adalah. tingkat keunggulan yang diharapkan dan pengendalian atas tingkat keunggulan tersebut untuk memenuhi keinginan pelanggan (Tjiptono dan Diana, 2003). Mutu pelayanan diketahui dengan cara membandingkan harapan / kepentingan pelanggan atas layanan yang ideal dengan layanan yang benar-benar mereka terima. Menurut Feigenbaum mutu merupakan kekuatan penting yang dapat membuahkan keberhasilan baik di dalam organisasi dan pertumbuhan lembaga, hal ini juga bisa diterapkan di dalam penyelenggaraan pelayanan mutu pendidikan. ${ }^{25}$ Selanjutnya jika mutu dikaitkan dalam penyelenggaraan pendidikan maka dapat berpedoman pada Undang-Undang Nomor 20 Tahun 2003 tentang Sistem Pendidikan Nasional dan Peraturan Pemerintah Nomor 19 Tahun 2005 tentang Standar Nasional Pendidikan yang menyatakan bahwa penjaminan mutu adalah wajib baik internal maupun eksternal.

\section{Mutu Pendidikan dalam Manajemen Berbasis Madrasah}

Dalam pandangan Umaedi (2004), mutu dapat diartikan sebagai derajat keunggulan sesuatu barang atau jasa dibandingkan dengan yang lain. Mutu dapat bersifat abstrak, misal dalam cara hidup yang bermutu, sikap hidup yang dilandasi oleh nilai-nilai yang dianggap luhur dan sangat dihormati.

Sallis dalam Total Quality Management in Education mengemukakan konsep mutu dalam 3 pengertian:

a. Mutu dalam Pengertian Absolut

${ }^{25}$ Fiegenbaum, A., V, Total Quality Control, New York, McGraw-Hill Book, 1996, hal. 98 
Dalam pengertian ini, mutu dianggap sesuatu yang ideal, seolah esensi dari kebaikan, keindahan, kebenaran, "tiada tanding", tiada banding" atau "tidak ada duanya".

b. Mutu dalam Pengertian Relatif

Mutu dalam pengertian ini bukanlah suatu sebutan untuk suatu produk atau jasa, tetapi pernyataan bahwa suatu produk atau jasa telah memenuhi persyaratan atau criteria atau spesifikasi yang ditetapkan (standar).

c. Mutu menurut Definisi Konsumen Organisasi atau lembaga-lembaga (termasuk madrasah) yang mengikuti pendekatan Total Quality Management atau TQM beranggapan bahwa "kualitas ditentukan oleh konsumen". Konsumen dianggap penentu akhir tentang mutu suatu produk atau jasa karena tanpa mereka, suatu organisasi/lembaga tidak dapat hidup atau tidak ada. ${ }^{26}$

Jadi mutu pendidikan adalah suatu pelayanan tentang keunggulan hasil kerja yang ditinjau dari segi input, proses, output, dampak maupun manfaat yang dapat ditingkatkan melalui manajemen berbasis madrasah (MBS). Mutu dalam pendidikan mengacu pada proses dan hasil pendidikan, seperti bahan ajar (kognitif, afektif dan psikomotorik), metodologi (bervariasi sesuai dengan kemampuan guru), sarana madrasah serta penciptaan suasana yang kondusif.

Salah satu indikator keberhasilan kepemimpinan seorang kepala madrasah diukur dari mutu pendidikan yang ada di madrasah yang dipimpinnya. Dalam konteks pendidikan, pengertian mutu mencakup input, proses, dan output pendidikan. ${ }^{27}$ Input pendidikan adalah segala sesuatu yang harus tersedia karena dibutuhkan untuk berlangsungnya proses.

Proses pendidikan merupakan berubahnya sesuatu menjadi sesuatu yang lain dengan mengintegrasikan input madrasah sehingga mampu menciptakan situasi pembelajaran yang menyenangkan (enjoyable learning), mampu mendorong motivasi dan minat belajar, dan benar-benar mampu memberdayakan peserta didik. Output pendidikan adalah merupakan kinerja madrasah yang dapat diukur dari kualitasnya, efektivitasnya, produktivitasnya, efisiensinya, inovasinya, dan moral kerjanya.

Dalam konsep yang lebih luas, mutu pendidikan mempunyai makna sebagai suatu kadar proses dan hasil pendidikan secara keseluruhan yang

\footnotetext{
${ }^{26}$ Sallis, E, Total Quality Management Education, London, Kogan Page Ltd, 2002, hal. 22-25

${ }^{27}$ Depdiknas, Manajemen Peningkatan Mutu Berbasis Madrasah, Jakarta, Depdiknas, 2001, hal.5
} 
ditetapkan sesuai dengan pendekatan dan kriteria tertentu. Proses pendidikan yang bermutu ditentukan oleh berbagai unsur dinamis yang akan ada dalam madrasah itu sendiri dan lingkungannya sebagai suatu kesatuan sistem. ${ }^{28}$ Menurut Townsend dan Butterworth (1992:35) dalam bukunya Your Child's Scholl, ada sepuluh faktor penentu terwujudnya proses pendidikan yang bermutu, yakni keefektifan kepemimpinan kepala madrasah; partisipasi dan rasa tanggung jawab guru dan staf; proses belajar-mengajar yang efektif;pengembangan staf yang terpogram; kurikulum yang relevan; memiliki visi dan misi yang jelas; iklim madrasah yang kondusif; penilaian diri terhadap kekuatan dan kelemahan; komunikasi efektif baik internal maupun eksternal; serta keterlibatan orang tua dan masyarakat secara instrinsik.

Berdasarkan konsep mutu pendidikan tersebut maka dapat dipahami bahwa pembangunan pendidikan bukan hanya terfokus pada penyediaan faktor input pendidikan tetapi juga harus lebih memperhatikan faktor proses pendidikan. Input pendidikan merupakan hal yang mutlak harus ada dalam batas-batas tertentu tetapi tidak menjadi jaminan dapat secara otomatis meningkatkan mutu pendidikan (school resources are necessary but not sufficient condition to improve student achievement).

Defenisi mutu memiliki konotasi yang bermacam-macam bergantung orang yang memakainya. Mutu berasal dari bahasa latin yakni "Qualis" yang berarti what kind of (tergantung kata apa yang mengikutinya). Mutu menurut Deming ialah kesesuaian dengan kebutuhan.Mutu menurut Juran ialah kecocokan dengan kebutuhan. ${ }^{29}$

Mutu di bidang pendidikan meliputi mutu input, proses, output, dan outcome. Input pendidikan dinyatakan bermutu jika siap berperoses. Proses pendidikan bermutu apabila mampu menciptakan suasana yang PAKEM (Pembelajaran yang Aktif, Kreatif, dan Menyenangkan). Output dinyatakan bermutu apabila hasil belajar akademik dan nonakademik siswa tinggi. Outcome dinyatakan bermutu apabila lulusan cepat terserap di dunia kerja, gaji wajar, semua pihak mengakui kehebatannya lulusannya dan merasa puas. ${ }^{30}$ Mutu dalam konteks

${ }^{28}$ Surya Dharma, Manajemen Kinerja: Falsafah Teori dan Penerapannya. Jakarta: Pustaka Pelajar, 2005, hal. 12 hal. 407

${ }^{29}$ Usman, Husaini, Manajemen Teori, Praktek dan Riset Pendidikan, Jakarta, Bumi Aksara, 2006,

${ }^{30}$ Ibid, hal. 410 
manajemen mutu terpadu atau Total Quality Management (TQM) bukan hanya merupakan suatu gagasan, melainkan suatu filosofi dan metodologi dalam membantu lembaga untuk mengelola perubahan secara totalitas dan sistematik, melalui perubahan nilai, visi, misi, dan tujuan. Karena dalam dunia pendidikan mutu lulusan suatu madrasah dinilai berdasarkan kesesuaian kemampuan yang dimilikinya dengan tujuan yang ditetapkan dalam kurikulum.

\section{E. Penutup}

Berdasarkan hasil analisis dan evaluasi pada pada pembahasan di atas maka dapat diambil beberapa kesimpulan bahwa komite madrasah memiliki peran penting sebagai pemberi perimbang, pendukung, pengontrol, dan sebagai mediator antara pemerintah dengan masyarakat di satuan pendidikan. Kepala madrasah sebagai top leader di lembaga pendidikan Islam maka kepala madrasah tentu memiliki peran strategi dalam mempengaruhi seganap stakeholder madrasah untuk mencapai tujuan pendidikan Islam. Secara bersama-sama komite madrasah dan kepala madrasah dalam meningkatkan mutu pendidikan Islam di madrasah.

\section{DAFTAR PUSTAKA}

Sadili Samsudin, Manajemen Sumber Daya Manusia. Bandung, CV.Pustaka Setia, 2006

Khoiruddin dan Mahfud Junaedi. Kurikulum Tingkat Satuan Pendidikan. Pilar Media. Jakarta, 2007

Arifin, Abdullrachman, Teori Pengembangan clan Filosofi Kepemimpinan Kerja.: Jakarta, Ikhtiar Baru, 2004

Slamet PH., “Karakteristik Kepala Madrasah Tangguh."'Jurnal Pendidikan dan Kebudayaan. (No. 025 tahun VI), 2000

Depdikbud, Kamus Besar Bahasa Indonesia, Pustaka Setia, Jakarta, 1992

Mahfud Junaed, KTSP, Pilar Media, Jakarta, 2007

UURI Nomor 20 Tahun 2003, Sistem Pendidikan Nasional, Jilid 4. Citra Umbara. Jakarta:5

Khoiruddin dan Mahfud Junaedi, Kurikulum Tingkat Satuan Pendidikan. Pilar Media. Jakarta, 2007 
Miftah Toha, Kepemimpinan dalam Manajemen. Jakarta, PT Raja Grapindo, 2003

Tjiptono, F., dan Diana, A, Total Quality Management, Yogyakarta: Penerbit Andi, 2003

Tilaar, H. A. R. Manajemen Pendidikan Nasional, Bandung: Remaja Rosdakarya, 1997

Sadili Samsudin, Manajemen Sumber Daya Manusia. Bandung, CV. Pustaka Setia, 2006

Soekarto Indarafachrudi, Bagaimana Memimpin Madrasah Yang Efektif, Bogor, Ghalia Indonesia, 2006

Maman Ukas, Manajemen. Bandung. Agini, 2004

Nanang Fatah, Manajemen Pendidikan, Bandung, Remaja Rosdakarya, 2009

Wahjosumidjo, Kepemimpinan dan Motivas. Bogor. Ghalia Indonesia, 2002

Rahman. et.al, Peran Strategi Kepala Madrasah dalam Meningkatkan Mutu Pendidikan, Jatinegara, Alqaprint, 2006

Depdiknas, Manajemen Peningkatan Mutu Berbasis Madrasah, Jakarta, Depdiknas, 2001

Muhammad Surya, Organisasi, Profesi, Kode Etik dan Dewan Kehormatan Guru. Jakarta, 2007

Depdikbud, Kamus Besar Bahasa Indonesia, Jakarta, Pustaka Setia, 1998

Syah, Muhibbin, Psikologi Pendidikan dengan Pendekatan Baru, Bandung, PT Remaja Rosda Karya, 2004

Umiarso \& Imam Gojali, Manajemen Mutu Madrasah di Era Otonomi Pendidikan, Jogjakarta, Ircisod, 2010

Fiegenbaum, A., V, Total Quality Control, New York, McGraw-Hill Book, 1996

Sallis, E, Total Quality Management Education, London, Kogan Page Ltd, 2002

Depdiknas, Manajemen Peningkatan Mutu Berbasis Madrasah, Jakarta, Depdiknas, 2001

Surya Dharma, Manajemen Kinerja: Falsafah Teori dan Penerapannya. Jakarta: Pustaka Pelajar, 2005

Usman, Husaini, Manajemen Teori, Praktek dan Riset Pendidikan, Jakarta, Bumi Aksara, 2006 